\title{
SIMBOLISASI PENDIDIKAN RELIGIUSITAS DALAM UPACARA AGAMA ISLAM DAN KATOLIK
}

\author{
A. Singgih Basuki \\ Universitas Islam Negeri (UIN) Sunan Kalijaga Yogyakarta \\ pipin_alice@yaboo.com
}

\begin{abstract}
Art in the religious point of view is as a symbols of human in which expressive and constructive based on their believe. In Islam and Catholic the symbol itself is abstract that fit to sociocultural and reflecting their believe. More over in constructing expressive symbols will make them more concern on their believe. The existance of art in Islam and Catholic is such an unity among religious experience and art itself. An expression of art in Islam is a fitrah (gift) for buman as a media in linking to Allah, but in Christian art is such praise and gratitude.
\end{abstract}

Keywords: Art, Simbols, Religiousity

\begin{abstract}
Abstrak
Seni dalam agama adalah simbolisasi manusia, bersifat ekspresif dan konstruktif yang berdasarkan sistem keyakinan. Pembentukan simbol dalam bentuk abstraksi baik dalam Islam maupun Katolik, disesuaikan dengan sosio-kultural masyarakat yang tidak mengurangi atau menyimpang dari prinsip akidab/keyakinan. Babkan dalam pembentukan simbol yang ekspresif, justru dapat menambab mutu atau semangat kesadaran beragama. Kehadiran seni dalam agama Islam dan Katolik merupakan suatu kesatuan yang akrab (lulub) antara pengalaman keimanan atau teologis dan seni atau estetis. Ekspresi seni dalam Islam merupakan fitrab manusia sebagai sarana mendekatkan diri kepada Allab sedangkan dalam Kristen merupakan ungkapan pujian dan puncak syukur kepada Tuban dalam bidup menggereja.
\end{abstract}

Kata kunci: Seni, simbolisasi, religiusitas. 


\section{Pendahuluan}

Di kalangan umat beragama pada umumnya, seni kurang mendapat perhatian bahkan cenderung dianggap kurang penting sehingga tidak bisa berkembang secara wajar. Padahal, sebagaimana diungkapkan oleh Mukti Ali, ada tiga hal yang sangat penting dalam hidup dan kehidupan manusia secara individu maupun kelompok yaitu seni, ilmu dan agama. Ketiga-tiganya akan menjadikan hidup dan kehidupan sempurna. Seni tanpa ilmu akan lunglai, seni tanpa agama akan kehilangan arah. Ilmu tanpa seni akan merupakan kekasaran-kekasaran, ilmu tanpa agama akan menjadi kebiadaban. Agama tanpa seni akan kering, agama tanpa ilmu akan lumpuh (Mukti Ali, 1972: 6). Sehingga dapat dikatakan bahwa dengan seni hidup menjadi halus dan syahdu, dengan ilmu hidup menjadi maju dan enak, dengan agama hidup menjadi bermakna dan bahagia.

Sejak awal penyebaran Islam di tanah Jawa, agama Islam dikenal memiliki hubungan adaptif dengan kebudayaan lokal. Agama Islam berpengaruh besar terhadap kehidupan kesenian rakyat. Di antara jenis kesenian yang cukup populer dan terkait dengan sistem ritual keagamaan masyarakat adalah seni Slawatan, yang merupakan perpaduan antara seni musik, sastra dan pertunjukan yang bercorak keislaman.

Sebuah kelompok seni Slawatan terdapat di Pedukuhan Kauman, Pleret, Bantul yang dikenal dengan Slawatan Montro "Suka Lestari". Slawatan yang menjadi kebanggaan masyarakat Kauman ini, selain sebagai sarana dakwah dan pendidikan keagamaan, juga menjadi sarana penghibur masyarakat dan pemupuk persatuan dan kesatuan. (GKTSM "Suka Lestari”, 1986: 2). Bagi penduduk Kauman Pleret, seni Slawatan bukan merupakan sesuatu yang asing, karena kesenian jenis ini sudah dikenal sejak waktu yang cukup lama. Sebelum lahir Slawatan Montro, pedukuhan ini sudah memiliki Slawatan Maulud.

Sementara itu dalam agama Katolik juga terdapat unsur-unsur seni dalam pelaksanaan Sakramen atau upacara keagamaan baik seni suara maupun seni rupa seperti nampak dalam tata-hias yang tidak hanya berupa benda yang biasa dikenal dalam Gereja pada umumnya. Di samping itu, terdapat juga kesenian yang bercorak 
tradisional pedesaan Jawa pada penyelenggaraan ritual agama yaitu di daerah Ganjuran, Bantul. Ritual agama seperti liturgi sebenamya merupakan suatu perayaan (celebration) yang berhubungan erat dengan masyarakat pedesaan itu' sendiri. Maksud ritual itu dapat pula diinterpretasikan sebagai suatu kontrol sosial, yaitu seperti banyak para ahli antropologi mengatakan, bahwa cara ritual agama pada dasarnya bermaksud untuk memperkuat tradisi ikatan sosial diantara sesama individu (Jabrohim, 1997: 21).

Dalam agama Katolik khususnya di Gereja lokal Ganjuran berkembang beberapa upacara antara lain upacara Liturgi Ekaristi yang dilaksanakan dengan berbagai macam cara yang dipakai oleh manusia sesuai dengan tabiat, perangai dan tradisi budayanya (Sacrosanctum Concilium 37-40; Konstitusi Liturgic 1990: 21-22). Misalnya menggunakan bahasa pribumi (Sacrosanctum Concilium 36), dalam hal ini bahasa Jawa, berbagai macam gerak isyarat, bunyibunyian atau nyanyian dengan musik gamelan Jawa, serta tanda ritual dalam berbagai macam bentuk simbolis seperti bahan sakramen lainnya. Dari semua realitas sosial yang diamati di atas, dapat ditarik makna teoretiknya yaitu adanya pembentukan simbol ekspresif dan komunikatif yang berbeda atau bervariasi (diferensiasi). Hal tersebut menunjukkan adanya berbagai pengalaman yang disesuaikan dengan kultur sosial masyarakat pendukungnya atau makna inkulturasinya.

Masyarakat Jawa khususnya masyarakat pedesaan dapat dikatakan sebagai masyarakat yang bersifat sosial-religius. Kepercayaan atau agama selalu menjiwai berbagai aspek kehidupan masyarakat, baik yang menyangkut sistem budaya maupun sistem sosialnya. Pokok masalah dalam penelitian ini berusaha mengkaji apakah pelembagaan agama dalam upacara dapat menjadi sarana pendidikan keagamaan; apakah simbol seni dalam ritual dapat meningkatkan kesadaran religiusitas dalam Islam dan Katolik serta mengapa terjadi diferensiasi dan inkulturasi pembentukan simbol ekspresif dalam ritual Islam dan Kristen. Karena yang diteliti lebih ke arah aspek sosial-seni-budaya, maka akan dicari dorongan apa yang menyebabkan timbulnya tingkah laku sosial itu. Berbagai aspek tertentu dari proses pengaruh-mempengaruhi antara tradisi agama dan kebudayaan Jawa setempat akan mengukuhkan beberapa penyesuaian atau perubahan kebudayaan. 
Tujuan yang ingin dicapai dari penelitian ini antara lain: memahami pelembagaan agama terutama yang berkaitan dengan ritual bisa menjadi alternatif sarana pendidikan keagamaan. Penelitian ini kemudian berusaha memahami bagaimana hubungan simbol konstitutif (agama) dan simbol ekspresif (seni) sebagai suatu sistem yang korelatif-integratif dan dinamis, atau bagaimana terjadinya pembentukan simbol seni dalam ritual dapat meningkatkan kesadaran religiusitas, maupun sebaliknya ritual agama dapat mengembangkan dorongan estetis. Di samping itu, tujuan penelitian ini ingin menelusuri sejauh mana pemahaman masyarakat dan fungsi kesenian dalam ritual agama.

\section{Metode Penelitian}

Penelitian ini menggunakan metode kualitatif dimana peneliti berusaha mendeskripsikan dan memahami fenomena sosial atau masyarakat sebagaimana masyarakat itu sendiri mempersepsikan diri mereka (to learn from the peoples) atau bersifat emik (emic-factors). Oleh karena itu realitas sosial atau masyarakat yang menjadi sasaran pengamatan tadi lebih dipahami sebagai suatu proses bukan kejadian semata-mata, yaitu subyek penelitian yang memiliki struktur, kelompok, perilaku, tindakan, kreativitas, dinamika, sikap dan citacita sesuai dengan diri mereka sendiri beserta lingkungannya. Dengan demikian penelitian ini menggunakan pendekatan etnografi yaitu lebih menggambarkan cara hidup atau kegiatan masyarakat Pleret dan Ganjuran dalam menginterpretasikan inkulturasi ritual agama sesuai dengan pandangan atau pemahaman masyarakat sendiri.

Atas dasar pendekatan di atas, maka beberapa langkah yang dilakukan antara lain sebagai berikut: Pertama, melakukan observasi di lapangan dengan mengamati berbagai kegiatan upacara salawatan dan liturgi agama pada konteks yang sebenarnya (truly natural context) dan bukan yang dibuat-buat (artificial context). Kedua, memahami makna atau nilai dari kegiatan itu sesuai dengan pandangan atau pemahaman para pelakunya sendiri- seperti pemimpin agama dan umat yang bersangkutan. Ketiga, berusaha mengkorelasikan beberapa temuan yang ada. Langkah terakhir atau keempat, setelah data dapat dipahami dengan mengkategorikan serta meng- 
identifikasikan berbagai macam karakteristik yang ada, maka setelah itu peneliti berusaha mengembangkan hipotesis, konsep dan teoriteori.

Pengumpulan data dilakukan dengan cara observasi . Dengan posisi ini peneliti mencoba memahami seting persoalan dengan menggali dan mengumpulkan bahan empirik untuk mengungkap permasalahan secara tuntas. Oleh karena itu keberadaan individu dalam berbagai kegiatan seperti beberapa pertemuan untuk melakukan kegiatan slawatan dan kegiatan ritual agama di Gereja, sembahyangan atau doa bersama di beberapa rumah penduduk, kegiatan berkesenian, dan kegiatan lainnya yang berhubungan dengan perayaan, direkam atau dicatat secara maksimal untuk memahami tindakan, reaksi, dan semua yang terkonstruksikan dalam kelompok itu. Pengalaman pengumpulan data primer diperoleh melalui wawancara dengan informan dan responden secara mendalam (indepth). Dimana wawancara bertujuan mendapatkan informasi atau keterangan khusus tentang pribadi, sikap, pendirian, atau pandangan dari individu yang diwawancarai untuk kepentingan komparatif (Koentjaraningrat, 1977: 163). Di samping data yang bersifat primer, juga dikumpulkan data yang berada di lapangan dengan melalui teknik dokumentasi sebagai pelengkap pendukung dengan teknik sebelumnya.

Data yang terkumpul dianalisis setiap waktu secara induktif dengan mengolah bahan empirik (synthesizing) supaya dapat disederhanakan ke dalam bentuk yang lebih mudah dibaca, dipahami dan diinterpretasikan. Data yang bersifat kualitatif diinterpretasikan untuk mencari makna dan implikasi hubungan yang ada (contextual analysis). Analisis induktif dimulai dengan merumuskan terlebih dahulu sejumlah permasalahan ke dalam beberapa pertanyaan atau isu spesifik yang dijadikan tujuan penelitian.

\section{Hasil Penelitian dan Analisis}

Dari penelitian terhadap keberadaan seni dalam Islam dan Gereja Katolik di lingkungan masyarakat pedesaan beserta upacaranya yang bersifat inkulturasi, terlihat dari beberapa kenyataan yang saling berhubungan, yaitu ajaran agama dan kebudayaan masyarakat itu 
sendiri. Islam mengajarkan rabmatan lil 'alamin dan Katolik menawarkan pada umatnya berbagai macam nilai yang membahagiakan sebagai ajaran keselamatan, antara lain melalui berbagai macam upacara ritual keagamaan dengan bermacam-macam simbol, sarana, tempat dan peralatan upacara lainnya. Melalui slawatan dan upacara di Gereja lokal dalam satu konteks budaya tertentu, berbagai upacara itu disesuaikan melalui proses inkulturasi. Tindakan individu, umat atau masyarakat dalam upacara liturgi tidak lepas adanya dimensi sosial serta keagamaan atau kepercayaan itu sendiri.

Membicarakan masalah kesenian sebagai karya atau hasil simbolisasi manusia merupakan sesuatu yang misterius. Berbagai macam definisi telah dikemukakan oleh para pakar atau seniman sendiri, tetapi sampai sekarang masih sering terjadi perdebatan atau adu pendapat terutama mengenai unsur "keindahan" yang dipersoalkan dalam berbagai macam teori seni. Bahkan bukan tak pernah terjadi dalam sejarah pemikiran akan kuatnya pengaruh dugaan teoritis, unsur keindahan ini sering dihubung-hubungkan dengan kebaikan maupun kebenaran.

Berbicara masalah unsur-unsur ritual agama, maka akan nampak erat berkaitan dengan seni. Kehadiran seni dalam ritual agama tidak dapat dielakkan lagi menjadi satu kesatuan yang akrab atau Jawa menyebut luluh, sebagaimana kegiatan itu di samping pengalaman keimanan, sekaligus juga pengalaman estetis. Fungsi seni sebagai ritual atau dalam pengertian upacara yang berhubungan dengan berbagai macam kepercayaan, telah berlangsung cukup lama semenjak munculnya kebudayaan primitif. Tentu saja pemahaman itu dimulai dari pengertian ritual yang paling mendasar dalam tata kehidupan atau peristiwa manusia yang penting dan juga pengertian seni sebagai ungkapan-ungkapan ekspresi-emosional yang sederhana. Berbagai macam bentuk ritual seperti itu merupakan transformasi simbolis dari beberapa pengalaman kebutuhan primer manusia dan merupakan kegiatan yang spontan, tanpa rancangan, dan kadang-kala tanpa disadari, namun polanya benar-benar alamiah. Kegiatan semacam ini dapat dilihat dalam pola-pola kepercayaan mitos dengan jenis-jenis ritus magi yang di dalamnya mengandung kekuatan yang menghubungkan kehendak manusia dengan penguasaanya dalam rangka menyiasati perjalanan alam dan mempengaruhi kekuatan lainnya. 


\section{Seni dalam Upacara Agama Islam}

Upacara yang dimaksud di sini adalah slawatan. Bermacam-macam nama jenis kesenian slawatan dengan ciri khasnya masing-masing antara lain slawatan, rodat, angguk, emprak, barjanjen, srokal, dilalak, kuntulan, badui, kobrasiswa, santiswara, debag, mondreng, panjidhur, trengganon, peksi moi dan gendring. Di antara beberapa nama itu, khususnya yang berkembang di wilayah Kauman Pleret antara lain slawatan, rodat, emprak dan gendring. Jenis kesenian rakyat ini mempunyai latar belakang keislaman, terutama pada mulanya berfungsi sebagai dakwah penyebaran agama Islam. Ciriciri itu dapat diketahui melalui beberapa syair yang biasa diucapkan atau dinyanyikan oleh para pemainnya. Kesenian ini merupakan jenis perpaduan antara seni gerak seperti pencak silat, tari dan seni suara. Di samping itu masih ada beberapa jenis kesenian yang menamakan dirinya dengan slawatan atau rodat saja namun ciri khasnya lebih didominasi oleh seni suara.

Pada mulanya jenis kesenian ini merupakan seni membaca kitab sastra berbahasa Arab yang disebut kitab Al-Barzanji dan Shalawat Badar secara berkelompok dalam posisi duduk di lantai. Seni membaca kitab ini kemudian berkembang dengan cara menyanyikan pujian yang berisi pengagungan Nabi Muhammad dan sahabatnya. Pada mulanya tanpa iringan instrumen musik apapun namun kemudian berkembang menjadi nyanyian yang diiringi musik non-gamelan seperti terbang dan jedhor atau kendhang besar. Beberapa jenis instrumen musik ini akhirnya menjadi ciri khas kesenian slawatan dan beberapa di antaranya berkembang, yaitu ada yang dipadu dengan jenis instrumen gamelan Jawa seperti kethuk, kempul, dan gong.

Beberapa jenis kesenian slawatan ada yang mernbawakan tema cerita secara samar seperti misalnya angguk dengan tema Islam yang di ambil dari cerita Menak. Beberapa penarinya juga sering mengalami peristiwa ndadi atau kemasukan (possessed) oleh roh halus dari tokoh-tokoh Menak seperti Umarmaya, Dewi Kuningkuning, Raden Satriya, Dewi Sekar Mawar (M. Umar Hadi, 1998:18). Fungsi kesenian ini di samping sebagai tontonan sekuler dalam rangka perayaan atau keperluan yang bersifat kesenangan semata- 
mata, namun juga berfungsi untuk melengkapi upacara ritual harihari besar Islam seperti memperingati Maulud Nabi, 1 Syura, upacara khitanan maupun perkawinan.

Ajaran Islam yang banyak mengkaitkan elemen-elemen estetis (seni) dalam agama, dalam arti dipercaya untuk keperluan ritual hanya terdapat dalam ajaran-ajaran mistik. Seperti laporan Arhsteles 1972 (dikutip Kuntowijoyo, 1987:55) yang berjudul Rumi: The Persian Sufi Rebirth in Creativity and Love. Di situ disebutkan bahwa ada sebuah kelompok yang disebut sam'a yang didirikan oleh Jalaluddin Rumi, dalam praktek perjalanan sejarahnya, berubah menjadi sebuah "agama" Rumi. Kelompok ini sering menyelenggarakan jenis tarian dengan nyanyian dan musik yang ekspresif dengan gerak berputarputar atau pusingan yang disebut The Whirting Der'uislr. Konon tarian itu sebagai pengganti dari bentuk sembahyang dan berfungsi sebagai upacara agama. Aliran lain yang mengkait-kaitkan elemen estetis dalam do'a terdapat juga dalam aliran Syi'ah. Islam aliran Syi'ah ini banyak mengembangkan tradisi do'a yang sangat puitis sebagai sebuah laku agarna. Beberapa contoh itu hanya merupakan sebagian kecil saja karena sebenarnya dalam ajaran yang asli, Islam tidak mengenal bentuk pelukisan atau penggambaran sesuatu seperti patung, lambang, maupun ritual dengan penyelenggaraan jenis pertunjukan. Seperti misalnya kebanyakan gerakan Sufi, melarang penggunaan musik dalam ritual peribadatannya.

Jika dilihat dari tradisi asal usul dan perkembangannya, ajaran Islam itu sebenarnya murni dan sederhana. Oleh sebab itu, misalnya jika ada keindahan lagu dalam shalat, tidak termasuk sebagai elemen estetis dalam ritual melainkan hanya bersifat atribut saja. Lagu dianggap tidak substansial atau tidak wajib (harus) dan bukan sunnah (dianjurkan). Dalam kedudukan teologisnya hanya bersifat bid'ah atau baru. Pada prinsipnya, ketentuan peribadatan dalam Islam menghindarkan pengalaman yang bersifat emosional seluruhnya namun lebih mengutamakan pengalaman agama yang benar-benar bersifat natural dan manusiawi untuk kepentingan pertumbuhan pribadi.

Di daerah Bantul khususnya, kesenian Slawatan ini cukup populer di kalangan masyarakat sehingga tidak hanya dipakai untuk 
keperluan yang berhubungan dengan tema keislaman saja, tetapi dalam perkembangannya juga digunakan untuk golongan agama lain seperti misalnya di Gereja Ganjuran Bantul. Kesenian Slawatan yang didominasi seni suara dengan iringan terbang dan jedhor ini berfungsi untuk mengiringi prosesi dan pentahtaan Sakramen Maha Kudus di depan gereja Ganjuran yang dilaksanakan pada setiap malam Jum'at pertama.

Kesenian jenis ini bagi penduduk Kauman Pleret sudah dikenal lama. Sebelumnya pedukuhan ini sudah memiliki Slawatan Maulud yang dipimpin oleh Bekel Kromosono dan Bekel Amat Songeb. Pendukungnya masih terbatas pada para sesepuh dan tokoh masyarakat setempat. Kelompok kesenian ini dinamakan Slawatan Maulud karena slawatan ini hanya pentas pada bulan Maulud (Rabi'ul Awal), tepatnya setiap malam tanggal 12 dalam rangka memperingati kelahiran (maulid) Nabi Muhammad saw. (GKTSM "Suka Lestari", 1986: 4). Naskah Slawatan Maulud tertulis dalam bentuk syair berbahasa Arab diselingi riwayat kelahiran Nabi Muhammad saw dalam bentuk prosa berbahasa Jawa. Di dalam pentas, naskah ini hanya dibacakan tanpa diiringi tarian. Adapun penyelenggaraan pentas selalu mengambil tempat di langgar milik Bekel Kromosono dan mendapat dukungan dari Kiai Mubarok dan para sesepuh desa pemeluk Islam yang taat beribadah.

Pada tahun 1939, ketika Pedukuhan Kauman menjadi bagian dari Kelurahan Nambangrejo, Slawatan Maulud berkembang menjadi Slawatan Montro tepatnya pada tanggal 11 April 1939. Tanggal kelahiran ini tertulis pada kulit sampul Telodho yang merupakan satu-satunya naskah acuan utama seni slawatan ini, serta tertulis pula pada pemukul kendhang. (GKTSM "Suka Lestari", 1986a:1) Slawatan ini dinamakan Montro, karena pada salah satu syairnya ada yang berbunyi "montro-montro" (GKTSM "Suka Lestari", 1986a: 2). Adapun syair atau tembang-tembangnya bersumber dari buku yang disebut Telodho karya Pepatih Dalem Kasultanan Mataram ing Ngayogyokarto Hadinigrat yang bergelar Kanjeng Pangeran Yudonegoro.. Tembang-tembang tersebut berisi riwayat kelahiran Nabi Muhammad saw yang digubah dan ditambah dengan bahasa Jawa agar mudah dipahami oleh orang-orang yang mendengarkannya (GKTSM "Suka Lestari", 1986a: 4). 
Kendati Slawatan Montro pada hakekatnya merupakan pengembangan dari Slawatan Mau1ud, namun slawatan Montro ini ada keunikannya yakni menggunakan bahasa Jawa.. Slawatan Maulud dibaca tanpa diiringi tarian, sedangkan Slawatan Montro dibaca dengan diiringi tarian. Hal yang terpenting dalam Slawatan Maulud adalah pembacaan riwayat Nabi Muhammad saw, sedangkan Slawatan Montro di samping mementingkan riwayat juga diselingi gendhing-gendhing rampak dan tarian dari para pemuda. Perbedaan lainnya yang nampak adalah pakaian personil Slawatan Maulud tidak seragam (bebas), sedangkan pakaian personil Slawatan Montro adalah seragam yang disesuaikan dengan peran masing-masing. Slawatan Maulud hanya pentas pada malam tanggal 12 Rabi'ul Awal (malam Grebeg) saja, sedangkan Slawatan Montro pentas kapan saja sesuai dengan kebutuhan. Keberadaan Slawatan Montro sejak awal sangat menarik bagi masyarakat Kauman. Mereka mulai latihan secara rutin dua minggu sekali dengan mengambil tempat di rumah salah seorang anggota secara bergiliran sebagaimana Slawatan Maulud, yaitu pada setiap tanggal 12 Rabi'ul Awal.

Slawatan Montro pentas semalam suntuk. Akan tetapi, dalam perkembangannya Slawatan Montro dipertunjukkan pula di luar bulan Maulud, seperti menyambut kelahiran bayi, khitanan, pernikahan, perayaan hari besar nasional, lomba seni, dan acaraacara lainnya. Pada masa sebelum kemerdekaan ketika Pedukuhan Kauman menjadi bagian dari wilayah Kelurahan Nambangrejo, Slawatan Montro pernah dipentaskan pada siang hari bolong, bertempat di sebidang sawah dekat sebuah kuburan di dekat Desa Gunungan. Ketika itu terjadi kemarau panjang yang menyebabkan Kelurahan Nambangredjo khususnya dan Kecamatan Pleret pada umumnya menderita kekurangan air. Lurah Desa Nambangrejo meminta agar Slawatan Montro bersedia pentas pada waktu dan tempat seperti disebut di atas, dengan maksud memohon kepada Tuhan Yang Maha Esa agar segera menurunkan hujan.

Setelah proklamasi kemerdekaan 17 Agustus 1945, pentas Slawatan Montro dilakukan pula pada setiap hari besar nasional, terutama dalam peringatan hari ulang tahun proklamasi kemerdekaan Republik Indonesia. Bahkan, sejak tahun 1985 pemerintah memanfaatkannya untuk memasyarakatkan program pembangu- 
nan, sehingga kegiatan pentas pada setiap tahunnya semakin sering dilakukan. Syair-syair yang ditembangkan dalam pentas pun akhirnya tidak lagi terbatas hanya dari buku terpilih, melainkan diselingi dengan pesan-pesan pembangunan, pembudayaan $\mathrm{P} 4$ dan program lain-lainnya.

Sampai saat penelitian ini dilakukan, Slawatan Montro masih merupakan salah satu kebanggaan penduduk Kauman Pleret dan belum pernah bisa ditemukan di daerah lain. Bagi penduduk Kauman sendiri, seni ini adalah satu-satunya seni pertunjukan yang dianggap sah berdasarkan tradisi, sehinga harus tetap dilestarikan. Masyarakat setempat percaya bahwa nenek moyang mereka pernah berpesan agar di Kauman tidak tumbuh kesenian lain, kecuali Slawatan Montro (GKTSM "Suka Lestari”, 1986a: 3). Sebagai upaya untuk melestarikan seni Slawatan Montro dan memperjelas identitasnya sesuai dengan tujuan semula, anggota group dan masyarakat Kauman sepakat memberi nama "Suka Lestari", sebagai kependekan dari: Slawatan Umat Islam Lelangen Sejarah lan Tari. (GKTSM "Suka Lestari", 1986a: 5)

Pada saat mengikuti Lomba Seni Tradisional Terbangan seKabupaten Bantul tahun 1985, Slawatan Montro Suka Lestari berhasil menjadi juara pertama, dengan memperoleh piala dan piagam penghargaan (Notulen Kegiatan, 1985-1993: 1). Dan dari waktu ke waktu terus berbenah diri, sehingga berkembang menjadi sebuah kelompok kesenian yang memiliki Anggaran Dasar dan Anggaran Rumah Tangga (AD/ART) dengan sistem administrasi yang relatif teratur.

\section{Seni dalam Upacara Agama Katolik}

Pelembagaan Gereja Katolik terjadi pada abad 19, kemudian dilanjutkan kegiatan misi yang baru, khususnya di pulau Jawa. Pada tahun 1802, hirarki pelembagaan Gereja Katolik di Nusantara ditingkatkan menjadi Prefektur Apostolik Katolik Betawi; dan baru pada tahun 1842 dinaikkan menjadi Vikariat Apostolik di bawah pimpinan seorang Vikaris Apostolik. Proses inkulturasi pelembagaan Gereja Katolik di Jawa dapat dikatakan mulai berkembang setelah munculnya Prefektur-prefektur maupun Vikariat baru di Jawa. Sejak 
itu secara pelan-pelan missi Gereja mulai melembaga sesuai dengan kebudayaan Jawa. Peristiwa ini bisa dicatat misalnya dengan adanya tiga orang misionaris yaitu Pater Hebrans yang akan menjalankan tugasnya di Semarang, Pater P. Hoevenaars yang akan ditempatkan di Yogya, dan kemudian Pater Fransiskus van Lith yang akan ditugaskan di daerah Muntilan, mulai mempelajari bahasa Jawa. Tiga orang missionaris dari Ordo Sarikat Jesus (SJ) inilah kelak nantinya merupakan tokoh-tokoh yang bekerja menggembalakan umat di sekitar Jawa Tengah setelah daerah ini dipisahkan dari Jakarta menjadi Vikariat Apostolik Semarang.

Gereja harus menjadi pelopor tanpa pamrih dalam menyesuaikan liturgi dengan tuntutan budaya dan tradisi bangsa-bangsa demi penghayatan yang otentik. Gereja berani mengadakan suatu pembaharuan yang radikal, sesuai dengan tuntutan inkarnasi, dan azas kesatuan dalam keanekaan (Sudarsono, 1992: 99). Setiap minggu terakhir bulan Juni, umat Katolik di paroki Gereja Lokal Ganjuran mengadakan suatu upacara atau perayaan yang mereka sebut sebagai "Ibadah Prosesi Sakramen Maha Suci". Sesuai dengan tradisi yang dilestarikan oleh Gereja itu, upacara ini dirayakan dengan adat-istiadat budaya Jawa sebagai perwujudan inkulturasi Gereja. Segala suasana perayaan dilakukan dengan nafas Jawa, sehingga sering dikatakan sebagai Liturgi Jawa. Perayaan Agung ini diselenggarakan dengan rnaksud: pertama, memperingati hari jadi paroki atau Gereja sesuai dengan pelindungnya yakni Hati Kudus Tuhan Yesus; kedua, mengenang jiwa, semangat, keutamaan, cita-cita dan harapan para leluhur yang telah menabur iman di Ganjuran; ketiga, sebagai ungkapan syukur atas berkat yang telah diterima selama itu, dan memohon berkat untuk perjalanan hidup menggereja dan memasyarakat pada masa yang akan datang; keempat, melestarikan tradisi warisan leluhur penyebar iman di Ganjuran yang telah melaksanakan usaha inkulturasi dalam rangka pembinaan iman sesuai dengan budaya Jawa selama ini.

Keempat tujuan itu pada hakikatnya juga merupakan tujuan liturgi, yaitu iman Gereja akan misteri penyelamatan Allah, di mana Gereja yang terbangun secara khusus diserahkan ke dalam pangkuan Hati Kudus Tuhan Yesus Kristus Raja yang bertahta dengan belas kasih hati-Nya yang Maha Kudus, dinobatkan dan diakui 
sebagai penguasa tanah Jawa, hingga akhirnya seluruh Nusantara juga dipersembahkan ke dalam pangkuanNya. Walaupun dianggap sebagai suatu upacara, tetapi peristiwa di atas ditekankan pada arti perayaan, sehingga dirayakan sebagai sebuah pesta, perjamuan, atau mereka sering menyebut pahargyan handrawina. Pesta perayaan itu seluruhnya diselenggarakan dari, oleh dan untuk umat. Kebersamaan, partisipasi, maupun keterlibatan pengalaman secara penuh, dimulai dari sejak persiapan hingga pelaksanaan, sungguh sangat mendapat tempat di hati masyarakat. Tradisi yang sesuai dengan sifat pedesaan yaitu gotong-royong, yang diwujudkan dengan persatuan, persaudaraan dan rasa kekeluargaan sebagai umat Allah, benar-benar dirasakan sebagai milik umat paroki Gereja Ganjuran dan sekitarnya.

\section{Ibadat Prosesi Sakramen Maha Kudus}

Liturgi Ekaristi sebagai suatu perayaan, pesta, perjamuan atau pahargyan, benar-benar dianggap sebagai sesuatu perhelatan besar atau mereka mengataka duwe gawe yang memerlukan persiapan secara matang. Bagi orang Jawa khususnya di lingkungan pedesaan, orang duwe gawe tidak hanya membutuhkan biaya saja tetapi juga tenaga dan pikiran dari sanak saudara, keluarga maupun tetangga dekat. Sebelum pembacaan Injil Kristus oleh imam sendiri sebagai Sabda atau Firman Tuhan, diselingi lagu antar bacaan atau Kidung Alleluya. Lagu Alleluya dinyanyikan seluruh umat dengan berdiri, bersemangat, karena lagu ini menggambarkan suasana mengagungkan kebesaran Tuhan, bahkan di antara umat ada yang dengan gerakan-gerakan mengangkat tangannya. Simbol-simbol gerakan ini dengan maksud meninggikan atau memuliakan Tuhan yang akan hadir dengan Firman-Nya.

Berbagai macam sirnbol ekspresif dan komunikatif (seni) yang bernafaskan Jawa (inkulturasi) membangkitkan suasana gembira, meriah, namun tetap khidmat. Dengan mengikuti upacara atau perayaan, di antara umat pernah mengalami hal-hal yang spektakuler (experiental involvement); merasakan keajaiban atau mukjizat dari Tuhan sendiri yakni merasakan kesembuhan, permohonan dikabulkan dan merasakan ketenteraman lahir maupun batin. Pada hakikatnya pelembagaan Gereja Lokal Ganjuran dengan 
pembentukan beberapa simbol yang selaras dengan situasi budaya setempat (inkulturasi) ini tanpa meninggalkan norma religius dan sakral sesuai dengan visi dan misi Gereja. Pemahaman fenomena sosial ini dalam wacana sosiologi budaya (sociology of culture) menyangkut tiga jenis studi atau komponen pokok : institutions, content, effect. (Cassirer, 1987, 55). Ketiga komponen ini menjadi suatu koherensi yang saling berhubungan satu dengan lainnya.

Seni dan agama atau religi mempunyai keterkaitan sangat erat apabila hanya membicarakan masalah unsur-unsur ritual dan emosional. Tetapi ketika agama berbicara masalah unsur kepercayaan dan rasional, nampaknya akan sulit untuk menghubungkan atau mengkaitkannya dengan seni. Karena itu, pada waktu pemikiran religius mencoba membangun pemahaman kepercayaan yang koheren, maka terjadilah pemikiran filosofis yang bersifat rasional. Di sinilah mulai nampak pemisahan atau bahkan saling bertentangan antara seni dan agama. Apa yang sering disebut-sebut "misteri" dalam seni berbeda dengan "misteri kepercayaan". Misteri seni merupakan suatu "ilham penciptaan" yang membuat obsesi manusia untuk mewujudkan karya seni yang bersifat subyektif bertentangan dengan rasio; sementara misteri iman adalah suatu kepercayaan yang kadangkala tidak dapat melepaskan rasio. Walaupun kepercayaan dan akal sering dipisahkan satu sama lain dan diberikan tempat tersendiri, tetapi keduanya tetap saling berhubungan. Misteri iman bukannya bertentangan dengan rasio, melainkan saling melangkapi dan menyempurnakan.

\section{Kedudukan Seni dalam Gereja Katolik}

Di dalam Gereja Katolik sebenamya seni diberi kebebasan untuk mengungkapkan keindahannya, sejauh kesenian itu dapat meningkatkan keindahan tata perayaan atau upacara-upacara Gereja, bahkan diharapkan dapat menopang atau mendorong kesadaran umat dalam beribadat. Gereja melalui Tahta Apostolik dan berbagai macam Konferensi Uskup di setiap daerah yang didirikan secara sah, memberi perhatian dan kesempatan kepada para seniman supaya dapat meresapi semangat kesenian ibadat dan liturgi-liturgi Gereja (Sacrosanctum Concilium I27). 


\section{a. Fungsi Sosial}

Seni sebagai ciptaan manusia yang muncul dari perasaan dan diwujudkan dalam bentuk simbol yang ekspresif, mempunyai berbagai macam fungsi. Salah satu fungsi yang mendasar adalah fungsi sosial. Seni menyandang fungsi sosial bersifat manusiawi, karena hakikat seni adalah untuk dikomunikasikan, berarti untuk dinikmati, ditonton, didengar atau diresapkan. Kehadiran seni mencakup tiga faktor inheren pada setiap manusia dalam segala tindakannya. Terutama dalam seluruh struktur liturgi Ekaristi yang intinya adalah rasa syukur (bergembira) atas misteri karya keselamatan Allah dalam Kristus. Elemen-elemen estetis dalam simbolsimbol seni yang hadir dalam liturgi itu akan mendorong perasaan syukur-bergembira. Oleh karena itu liturgi Ekaristi di samping sebagai pengalaman keimanan juga dikatakan pengalaman estetis. Pandangan umat di Gereja Ganjuran menunjukkan bahwa pengalaman keimanan tak dapat dipisahkan dengan pengalaman estetis (seni). Di antara mereka mengatakan: olab seni ingkang sarwa "endab" meniko mujudaken ugi kaluburan tumrap kapitadosan dhumateng agami (karya seni yang serba "indah" mewujudkan pula keluhuran terhadap kepercayaan agama). Pengertian itu dipahami karena unsur keindahan seni tidak ada artinya bila tidak mengandung muatanmuatan yang bersifat kebaikan, kebenaran dan juga keluhuran manusia.

Kehadiran seni dalam upacara atau perayaan liturgi Ekaristi ini dapat mewujudkan sifat kebersamaan dan toleransi sesama pengikut kepercayaan lain, baik dari sejak persiapan sampai pelaksanaannya rnereka ikut berpartisipasi dalam kegiatan seni yang ditampilkan dalam upacara atau perayaan itu. Masyarakat setempat yang tidak seiman tertarik membantu pelaksanaan perayaan itu, menganggapnya sebagai kegiatan moral kegotong-royongan sesama warga desa dan atas dorongan estetis itu sendiri. Melalui ritual agama yang penuh dengan berbagai macam simbol seni tidak hanya merupakan alat efektif untuk menghimpun umat komunitas, tetapi juga memantapkan solidaritas dan koherensi kelompok.

Mereka yang tampil dalam kegiatan itu menyadari ataupun merasakan suatu belonging atau keikutsertaan, kebersamaan dan 
menyegarkan kontak sosial yang masa-masa seperti sekarang ini jarang terjadi karena disibukkan oleh berbagai macam urusan yang bersifat duniawi. Upacara atau perayaan yang penuh dengan pengalaman keimanan dan pengalaman estetis ini, merupakan sesuatu yang sangat berharga, yang telah diperankan oleh agama dalam kehidupan masyarakat pedesaan dengan sifat-sifat kegotongroyongannya.

\section{b. Fungsi Ritual}

Seperti yang pernah dikatakan oleh Al-Faruqi (1999: 44-64), ketika agama berbicara masalah unsur-unsur ritualnya, maka di situ nampak agama erat berkaitan dengan seni. Kehadiran seni dalam ritual agama tidak dapat dielakkan lagi menjadi satu kesatuan yang akrab atau Jawa menyebut luluh. Sebagaimana kegiatan itu sendiri, di samping merupakan pengalaman keimanan, sekaligus juga pengalaman estetis. Fungsi seni sebagai ritual atau dalam pengertian upacara yang berhubungan dengan berbagai macam kepercayaan, telah berlangsung cukup lama semenjak munculnya kebudayaan primitif. Tentu saja pemahaman itu dimulai dari pengertian ritual yang paling mendasar dalam tata kehidupan atau peristiwa manusia yang penting, dan juga pengertian seni sebagai ungkapan-ungkapan ekspresi emosional yang sederhana. Berbagai macam bentuk ritual seperti itu merupakan transformasi simbolis dari beberapa pengalaman kebutuhan primer manusia, maka ia merupakan kegiatan yang spontan, tanpa rancangan, dan kadangkala tanpa disadari, namun polanya benar-benar alamiah. Kegiatan semacam ini dapat dilihat dalam pola-pola kepercayaan mitos dengan jenis-jenis ritus magi yang di dalamnya terdapat simbol ekspresif dan komunikatif (seni) yang bernafaskan Jawa (inkulturasi), dapat membangkitkan suasana gembira, meriah namun tetap khidmat. Dengan mengikuti upacara atau perayaan, di antara umat pernah mengalami hal-hal yang spetakuler (experiental involvement) merasakan keajaiban atau mukjizat dari Tuhan sendiri yakni merasakan kesembuhan, permohonan dikabulkan dan merasakan ketenteraman lahir maupun batin.

Pada hakikatnya pelembagaan Gereja Lokal Ganjuran dengan pembentukan beberapa simbol yang selaras dengan situasi 
budaya setempat (inkulturasi) ini tanpa meninggalkan norma religius, dan sakral, sesuai dengan visi dan misi Gereja. Pemahaman fenomena sosial ini dalam wacana sosiologi budaya (sociology of culture) menyangkut tiga jenis studi atau komponen pokok: institutions, content, efect. (Turner, 1983: 34). Ketiga komponen ini menjadi suatu koherensi yang komponennya saling berhubungan satu sama lain.

Ritual agama atau Liturgi Ekaristi ini adalah suatu bentuk upacara atau perayaan (celebration) yang mengakup segala sesuatu yang dibuat atau dipergunakan oleh manusia untuk menyatakan hubungan dengan yang "tertinggi" dan bersifat transendental; dan relasi yang diwujudkan dalam bentuk upacara ritual itu bukan sesuatu yang sifatnya biasa, tetapi bersifat khusus, istimewa dan sakral, sehingga manusia menyelenggarakan suatu cara yang dianggap pantas guna melaksanakan pertemuan sakral itu.

Pembentukan simbol dalam liturgi bukanlah simbol yang kosong atau sekedar sebagai penunjuk jalan saja, tetapi merupakan simbol suci (sacred), yang berdaya guna, yakni simbol yang melaksanakan dan menghadirkan secara efektif apa yang dilambangkan itu. Pengertian ini memberikan arti penting bahwa liturgi bersifat sakramental, yaitu Kristus hadir bersatu dengan manusia secara sakramental dalam bentuk simbol. Seluruh aktivitas dan segala macam benda perayaan liturgi yang terjadi dalam realitas sosial, dilaksanakan dan diwujudkan dalam bentuk simbol. Artinya setiap unsur yang digunakan serta segala aktivitas dalam liturgi itu bercorak simbolis. Dalam liturgi Jawa ini sungguh sangat kaya pembentukan simbol, tetapi dalam pemaparan ini tidak dimaksudkan untuk mengungkap seluruhnya.

Beberapa simbol dan aktivitas yang cukup penting mendukung pelaksanaan liturgi Jawa di atas antara lain berupa candi Ganjuran atau disebut candi Hati Kudus Yesus yang bercorak Hindu Jawa gabungan Mataram Kuno dan Majapahit ini dipakai sebagai tempat upacara atau perayaan liturgi. Candi yang dibangun sejak 1927, yang difungsikan sampai sekarang, menunjukkan pembentukan sirnbol yang sangat penting sebagai tempat upacara liturgi Jawa. Goa Maria Sendangsono merupakan monumen kelahiran murid Kristus dengan peristiwa permandian umat Katolik pertama pada 
tahun 1904, sementara Ganjuran dengan candinya merupakan monumen perutusan murid Kristus. Bagi umat Katolik yang berziarah ke Sendangsono, akan menjadi lebih lengkap apabila juga berziarah ke candi Ganjuran. Goa Maria Sendangsono dan Candi Hati Kudus Yesus Ganjuran merupakan simbol monumen umat yang diutus oleh Allah sendiri. Candi ini juga dianggap sebagai sumber kehidupan suci mirip atau kembaran seperti sumber air sendang di Sendangsono, karena tepat di bawah bangunan candi pada tahun 1998 ditemukan sumber air. Sumber air ini sekarang disalurkan menjadi beberapa kran yang berjumlah sembilan, ditempatkan di belakang candi yang dapat dimanfaatkan oleh semua umat atau peziarah yang datang; dan sekarang dipercaya sebagai air suci kehidupan. Air ini kemudian disebut "Tirta Perwitasari" yaitu mengabadikan nama Bapak Perwitasari, orang pertama yang karena imannya merasakan daya penyembuhan air candi ini.

Dalam uraian sebagaimana di atas nampak bahwa di dalam berkesenian, baik dalam Islam maupun Katolik, terlihat sebuah bentuk penghayatan agama yang tidak formalistik namun lebih mementingkan substansi beragama itu sendiri, yaitu kedekatan dengan Tuhan serta kedamaian dengan sesama. Terwujudnya ragam beragama seperti ini adalah berkat nilai-nilai agama dan unsurunsur tradisi masyarakat lokal lebur menjadi sebuah entitas budaya yang indah. Namun, model beragama secara kultural yang berbasis kesenian lokal khususnya dalam masyarakat Jawa yang menjadi obyek penelitian ini, cenderung dilupakan dan dianggap bukan sesuatu yang penting untuk didiskusikan. Padahal, secara nyata dapat dilihat bahwa melalui seni dan budaya, agama memancarkan sinar-sinar kedamaian dalam kehidupan manusia sehari-hari, tanpa tersekat oleh faham dan golongan. Maka secara langsung maupun tidak langsung, seni yang melekat pada ritual agama bisa menjadi alternatif pendidikan keagamaan dalam rangka menghaluskan jiwa dan budi pekerti.

Sejak pertama kali lahir, sesungguhnya agama sudah mengamanatkan kepada pemeluknya untuk mendialogkan agama dengan budaya dalam rangka mewujudkan masyarakat yang damai dan nyaman. Agama seolah menjadi bagian dari dirinya, dan sebaliknya dirinya menjadi bagian dari agama. Pola keberagaman 
kultural yang berbasis seni seperti ini terabaikan oleh penganjurpenganjur agama pada umumnya. Mendialogkan antara agama dan budaya yang berbasis seni ke depan hendaknya menjadi agenda yang perlu dikembangkan dan digalang bersama oleh segenap komponen umat beragama sebagai alternatif pendidikan keagamaan dalam rangka menyajikan sebuah agama yang damai, toleran dan manusiawi.

Ketika agama disampaikan tidak melalui media budaya masyarakat, ia akan menggiring lahirnya ideologisasi "semu" terhadap agama, yaitu suatu sikap yang mengedepankan dimensi legal-formal yang tidak berpijak pada ruh dan nafas kehidupannya. Hal ini terjadi karena masyarakat tidak diajak untuk memahami, tetapi meyakini sebuah agama. Dengan cara seperti ini, agama akan menjelma menjadi simbol sebuah eksistensi. Ia lahir bukan dari sebuah refleksi kesadaran yang sesungguhnya, melainkan lebih merupakan sebuah upaya penguatan status quo agama itu sendiri. Konseksuensi lainnya adalah masyarakat menyikapi agama bukan sebagai ajaran untuk belajar memilih yang terbaik dan mencapai kebenaran abadi. Ia telah dijadikan sebagai ajaran yang sudah final dan bertugas menghakimi kenyataan yang ada. Masyarakat pun tidak terbiasa dan berani memahami agama di luar apa yang ia dengar dan liturgi. Mereka secara otomatis dibuat tidak berdaya untuk membedakan mana yang murni agama (tekstual) serta mana yang bukan (kontekstual). Keberagamaan seperti ini akan melahirkan sikap eksklusif dan merasa paling agamis. Mereka yang berada di luar pemahaman dirinya dinilai sebagai kelompok yang kurang agamis.

Melihat fenomena seperti ini, paling tidak, agama harus menjelma menjadi sebuah kesadaran yang terbangun bersama dalam kultur masyarakat. Ia tidak terasing dari budaya masyarakatnya karena berada di luar budaya bahkan menjadi hakim bagi budaya. Sebaliknya nilai-nilai agama melebur atau luluh dengan budaya sehingga irama dan gerak kehidupan masyarakat secara tidak langsung memancarkan nuansa agamis. Penghayatan agama seperti ini tidak akan terwujud dengan semaraknya aktifitas dakwah dengan lisan sebagaimana yang sering digelar selama ini, namun melalui penanaman nilai keberagamaan yang terpancar dari sikap dan perilaku para tokoh dan pemimpin agama. 


\section{Kesimpulan}

Berdasarkan uraian dalam penelitian yang dilakukan maka dapat disimpulkan bahwa: Kesenian sebagai unsur kebudayaan tidak hanya sebagai hasil kreasi manusia, tetapi lebih dipandang sebagai suatu simbol atau lambang yang sarat dengan makna dan pesan untuk diresapkan. Seni sebagai hasil kreasi manusia disebut karya seni adalah hasil simbolisasi manusia. Pelembagaannya baik dalam Islam maupun Kristen yang membentuk kesenian lokal berupa Slawatan Montro maupun Liturgi Ekaristi, mampu memberikan alternatif pendidikan keagamaan di komunitas masing-masing.

Pembentukan berbagai macam liturgi seni baik Islam maupun Katolik, telah disesuaikan dengan sosio-kultural masyarakat yang tidak mengurangi atau menyimpang dari kaidah agama maupun Iman Kristen. Seni dalam Slawatan Montro dan Liturgi Ekaristi bukan merupakan esensi agama melainkan sebagai atribut. Dengan pembentukan seni yang ekspresif, justru dapat menambah mutu atau semangat kesadaran beragama atau religiusitas. Pengalaman keagamaan dalam hal ini tidak hanya sebagai pengalaman keimanan namun juga pengalaman estetis yang melibatkan perasaan dan tindakan.

Kehadiran seni dalam ritual agama tidak dapat dielakkan lagi menjadi satu kesatuan yang akrab atau dalam bahasa Jawa disebut luluh. Kegiatan tersebut di samping merupakan pengalaman keimanan juga pengalaman estetis. Fungsi seni sebagai ritual atau dalam pengertian upacara yang berhubungan dengan berbagai macam kepercayaan telah berlangsung cukup lama semenjak munculnya kebudayaan liturgi. Seni dalam agama Islam merupakan fitrah manusia dan kesenian merupakan sarana untuk mendekatkan diri kepada Allah. Kesenian yang diwujudkan dalam bentuk upacara keagamaan di antaranya adalah Slawatan. Seni dalam Slawatan dapat meningkatkan semangat dan gairah dalam beragama serta penghayatan yang mendalam dalam menjalankan kegiatan agama. Secara langsung maupun tidak langsung, Slawatan menjadi sebuah media pendidikan keagamaan dalam rangka memperhalus jiwa dan budi pekerti. 


\section{Daftar Pustaka}

Ali, A. Mukti. 1972. Seni, Ilmu dan Agama, Yogyakarta: Yayasan Nida.

Al-Faruqi, Ismail Raji. 1999. Seni Taubid, Esensi dan Ekspresi Estetika Islam, penerjemah Hartono Hadikusomo, Yogyakarta: Yayasan Benteng Budaya.

Cassirer, Ernst. 1987. Manusia dan Kebudayaan: Sebuab Essei Tentang Manusia. Terj. Alois A.Nugroho. Jakarta: PT. Gramedia.

Geerts, Clifford. 1989. Abangan, Santri, Priyayi dalam Masyarakat Jawa, penerjemah, Aswab Mahasin, cet. ke-3, Jakarta: Pustaka Jaya,

Grup Kesenian Tradisionil Slawatan Montro (GKTSM). 1986. "Suka Lestari”, Yogyakarta.

Hadi, M. Umar, 1998. Simbol, Arti dan Penerapannya dalam Pidato Ilmiah. Dies Natalis XIV Institut Seni Indonesia Yogyakarta. Yogyakarta: Kamis, 23 Juli 1998.

Israr,C.. 1955. Sejarah Kesenian Islam, Djakarta: PT. Pembangunan. Jabrohim dan Saudi Berlian (ed.). 1995. Islam dan Kesenian, Yogyakarta: Majelis Kebudayaan Muhammadiyah - Universitas Ahmad Dahlan - Lembaga Litbang PP Muhammadiyah.

Koentjaraningrat. 1994. Kebudayaan Jawa, cet. ke-2, Jakarta: Balai Pustaka.,

Kuntowijoyo. 1987. Budaya dan Masyarakat, Yogyakarta: Tiara Wacana.

Mandala Wisata Daerah Istimewa Yogyakarta, Jakarta: Direktorat Sejarah dan Nilai Tradisional Direktorat Jenderal Kebudayaan Depdikbud RI.

Mastuhu. 1999. Memberdayakan Sistem Pendidikan Islam, Jakarta: Logos Wacana Ilmu.

Saridjo, Marwan. 1996. Bunga Rampai Pendidikan Agama Islam, Jakarta: CV Amissco.

Shaleh, Abdul Rachman. 2000. Pendidikan Agama dan Keagamaan, Jakarta: Gema Windu Perkasa.

Sudarsono. R.B.. 1992. "Seni Musik" dalam Soedarsono, (ed). 
Pengantar Apresiasi Seni, Jakarta: Balai Pustaka.

Sudiardja, A, Susanne K. LUV.. 1983."Pendekatan Baru Dalam Estetika', dalam M. Sastrapratedja (ed). Manusia Multi Dimensional. Sebuah Renungan Falsafi, Jakarta: PT. Gramedia.

Suryo, Djoko, R.M. Soedarsono, Djoko Sockiman. 1985. Gaya Hidup Masyarakat Jawa di Pedesaan: Poles Kebidupan Sosial - Ekonomi dan Budaya. Yogyakarta: Proyek Penelitian \& Pengkajian. Kebudayaan, Dir. Jen. Kebudayaan, Dep. P \& K,

Suseno, Franz Magnis. 1980. "Mewartakan Injil dalam Masyarakat Jawa: Beberapa, Catatan tentang Kemungkman Inkulturasi Gereja di Alam Jawa" dalam Orientasi Pustaka Filsafat dan Teologi. 12.

Tolstoy, Leo N.. 1960. What is Art, Indianapolis, New York: BobbsMerrill Company Inc.

Tuntunan Misa Prosesi Paroki Ganjuran. 1997. Yogyakarta: Paroki Ganjuran.

Turner, Bryan S.. 1983. Religion and Social Theory: A Materialist Perspective, London: Heinemaim.

Watts, Alan W.. 1964. Myth and Ritual in Christianity, Boston: Beacon.

Woodward, Mark R.. 1989. Islam in Java, Normative Piety and Mysticism in the Sultanate of Yogyakarta, Tueson: The University of Arizona Press.

Yudoseputro, Wiyoso. 1992. "Seni Rupa", dalam Soedarsono, (ed), Pengantar Apresiasi Seni. Jakarta: Balai Pustaka. 